JOSAR, Vol. 1 No. 2 September, 2018; p-ISSN: 2502-8251; e-ISSN: 2503-1155

Copyrights@ Balitar Islamic University, Blitar-Indonesia https://ejournal.unisbablitar.ac.id/index.php/josar

\title{
PLANT DISTANCE RESPONSE TO GROWTH AND RESULTS OF BUNCIS NUT (Phaseolus vulgaris L.) PLANTS IN VARIOUS SOLID BIOSLURRY DOSAGE
}

\author{
Sepvi Indah Purwanti \\ ${ }^{1,2}$ Islamic University of Balitar; Jl. Majapahit No.04, Telp. (0342) 813145 \\ ${ }^{3}$ Agribisnis department, FP Islamic University of Balitar, Blitar \\ e-mail: sepviindah95@gmail.com,
}

\begin{abstract}
ABSTRAK
This study aims at 1) to determine the interaction of planting spacing and bioslurry doses on the growth and yield of beans. 2) to determine the effect of planting distance on the growth and yield of beans. 3) to determine the effect of dense bioslurry doses on the growth and yield of beans. The research using Split Plot 2 factorial was repeated 3 times. The first factor is distance $(\mathrm{J})$ which consists of 3 levels, namely: $20 \times 50 \mathrm{~cm}(\mathrm{~J} 1), 20 \times 60 \mathrm{~cm}$ (J2), $20 \times 70 \mathrm{~cm}$ (J3). The second factor is a solid bioslurry dose (B) consisting of 3 levels: $B 1=500 \mathrm{~kg} . \mathrm{Ha}-1, B 2=600 \mathrm{~kg}$. Ha-1, B3 = $700 \mathrm{~kg}$. Ha-1. The results showed that there were interactions between plant spacing and bioslurry doses on the number of pods with the highest yield in J2B3 treatment, ie 59.33, pod weight by plant with the highest yield in J2B2 treatment, namely $390.27 \mathrm{gr} /$ plant and pod weight by plot with the highest yield in J2B3 treatment, which is $5993.75 \mathrm{gr} / \mathrm{plo}$
\end{abstract}

\section{Keywords: Peanuts, Solid Bioslurry Doses, Spacing}

\section{INTRODUCTION}

Beans (Phaseolus vulgaris L.) is one of the legume plants that has a fairly high nutritional value, where every 100 grams of fresh beans contain thianin, 88.3 calories, 2.5 grams of protein, 0.2 grams of fat, $88 \mathrm{ml}$ water, 7 grams of carbohydrates, 1.8 grams of fiber and vitamins $A$ and $C$ (Cahyono, 2003).

Bean production in Indonesia increased from 2008 to 2012, amounting to 266,551 tons to 338,655 tons. Bean production in Indonesia is still not enough to meet people's needs. Therefore, Indonesia imports beans of 30,909 tons to meet people's needs (BPS, 2012). Increasing bean production has an important meaning in supporting the improvement of people's nutrition. Efforts to increase the production of appropriate beans can be done by determining the spacing, use of subyior varieties, irrigation and proby fertilization. 
According to Andrianto (2004) the spacing used in the cultivation of beans is $20 \times 50 \mathrm{~cm}$, both for sloping and flat soil. If soil fertility is high, it is better to use a closer spacing of $20 \times 40 \mathrm{~cm}$. This aims to prevent the growth of weeds that will grow faster in fertile soil. Determination of spacing is closely related to the availability of nutrients, water and solar energy, therefore determining the spacing must be considered.

In addition to the use of spacing in cultivation, fertilizer use also plays an important role in optimizing the production of cultivated plants. However, the provision of excess fertilizer can be detrimental to the plant itself, therefore in achieving success in cultivation it is necessary to understand the correct fertilizer and fertilization.

Bioslurry or waste gas is the result of biogas processing consisting of livestock manure and water through an anaerobic process. One result of an anaerobic process is the formation of liquid waste called bioslurry. Liquid or solid waste can be used as organic fertilizer (Yunnan Normal University, 2010).

Bioslurry contains macro and micro elements needed for plant growth. Macro elements in bioslurry are Nitrogen $(N)$, Potassium $(K)$, Phospor (P), Calcium (Ca), Magnesium (Mg) and Sulfur (S), while the micro elements needed are Iron ( $\mathrm{Fe})$, Manganese (Mn), Copby (Cu), and Zinc (Zn). In addition to containing macro and micro elements, bioslurry also contains organic ingredients of $68.59 \%$, C-org $17.87 \%, N 1.47 \%, P$ $0.52 \%, \mathrm{~K} 0.38 \%$ and C / N $9.09 \%$. By making bioslurry as organic fertilizer it will have a good influence on plant growth and be able to improve soil structure and fertilize the soil (Agus, 2013).

\section{RESEARCH METHODS}

The study was conducted using the Split Pot Design method. The treatment consisted of two factors, namely planting distance $(\mathrm{J})$ and bioslurry dose, with repeated three times. The first factor: spacing $(\mathrm{J})$ consists of three levels, namely: $\mathrm{J} 1=20 \times 50 \mathrm{~cm}, \mathrm{~J} 2=20 \times 60 \mathrm{~cm}, \mathrm{~J} 3=$ 
$20 \times 70 \mathrm{~cm}$. The second factor: bioslurry dose $(B)$ consists of three levels, namely: B1 $=500 \mathrm{~kg} . \mathrm{Ha}-1, \mathrm{~B} 2=600 \mathrm{~kg} . \mathrm{Ha}-1, \mathrm{~B} 3=700 \mathrm{~kg} . \mathrm{Ha}-1$. Analysis of data using variance at the level of $5 \%$, if there is a difference between treatments, it will be followed by a tukey test. The variables observed were: leaf area, stem diameter, pod length, number of pods / plants, pod / plant weight, pod / plot weight.

\section{RESULTS AND DISCUSSION}

\section{A. Leaf area}

Based on analysis of variance (ANOVA) level of $5 \%$ showed that there was no significant interaction between treatment of spacing $(\mathrm{J})$ and bioslurry dose (B) on leaf area of bean plants at all ages of observation. Can be seen in table 1 .

Table 1. Leaf Area (cm2) in Exbyiments the Effect of Distance (J) and Bioslurry Dosage (B)

\begin{tabular}{lllll}
\hline \multirow{2}{*}{ Treatment } & \multicolumn{4}{l}{ Leaf Area $\left(\mathrm{cm}^{2}\right)$} \\
& 21 hst & 28 hst & 35 hst & 42 hst \\
\hline Planting Distance & & & & \\
J1 (20x50) & $57.58 \mathrm{a}$ & $67.39 \mathrm{a}$ & $72.68 \mathrm{ab}$ & $79.95 \mathrm{a}$ \\
J2 $(20 \times 60)$ & $54.69 \mathrm{a}$ & $68.35 \mathrm{a}$ & $77.21 \mathrm{~b}$ & $78.95 \mathrm{a}$ \\
J3 (20x70) & $51.52 \mathrm{a}$ & $65.03 \mathrm{a}$ & $70.97 \mathrm{a}$ & $74.62 \mathrm{a}$ \\
Bioslurry dosage & & & & \\
B1 (500 kg/ha) & $52.25 \mathrm{a}$ & $65.13 \mathrm{a}$ & $72.19 \mathrm{a}$ & $76.84 \mathrm{a}$ \\
B2 $(600 \mathrm{~kg} / \mathrm{ha})$ & $56.52 \mathrm{a}$ & $67.18 \mathrm{a}$ & $73.43 \mathrm{a}$ & $77.44 \mathrm{a}$ \\
B3 $(700 \mathrm{~kg} / \mathrm{ha})$ & $55.01 \mathrm{a}$ & $68.46 \mathrm{a}$ & $75.24 \mathrm{a}$ & $79.23 \mathrm{a}$ \\
\hline
\end{tabular}

Description: The numbers followed by the same letter in the same row and column are not significantly different from the DMRT test $(\alpha=0.05)$.

The planting distance treatment has significant differences at the age of 35 days with the best treatment on the treatment spacing of $20 \times 60 \mathrm{~cm}$ (J2). This is presumably because the wider leaf area and not shading each other will have a greater chance of utilizing sunlight that is captured by the leaves to be used as energy in the process of photosynthesis, so the photosynthate will be better. Photosynthetic photosynthates are used by 
plants for the growth of beans and in the generative byiod will be allocated for pod formation. This is in accordance with the opinion of Setyanti (2013), describing that leaf area affects the quantity of sunlight absorption. If nutrients and sunlight are sufficient, it will result in an increase in the number of branches or leaves that grow and plants will also increase the rate of growth in order to be able to capture the maximum sunlight so that the photosynthesis process runs smoothly.

\section{B. Stem Diametre}

Based on the analysis of variance (ANOVA) level of $5 \%$ showed no significant interaction between the effect of spacing $(\mathrm{J})$ and bioslurry dose (B) on stem diametre of chickbean at all ages of observation, but at plant age 42 days there were significant differences. Can be seen in table 2 Table 2. Stem Diametre $(\mathrm{cm})$ in Exbyiments the Effect of Distance $(\mathrm{J})$ and Bioslurry Dosage (B)

\begin{tabular}{lllll}
\hline \multirow{2}{*}{ Treatment } & \multicolumn{3}{l}{ Stem Diameter $(\mathrm{cm})$} \\
& $21 \mathrm{hst}$ & $28 \mathrm{hst}$ & $35 \mathrm{hst}$ & $42 \mathrm{hst}$ \\
\hline Planting Distance & & & & \\
J1 (20x50) & $0.47 \mathrm{a}$ & $0.58 \mathrm{a}$ & $0.67 \mathrm{a}$ & $0.72 \mathrm{a}$ \\
J2 (20x60) & $0.43 \mathrm{a}$ & $0.58 \mathrm{a}$ & $0.71 \mathrm{a}$ & $0.78 \mathrm{ab}$ \\
J3 (20x70) & $0.45 \mathrm{a}$ & $0.61 \mathrm{a}$ & $0.74 \mathrm{a}$ & $0.82 \mathrm{~b}$ \\
Bioslurry dosage & & & & \\
B1 (500 kg/ha) & $0.45 \mathrm{a}$ & $0.57 \mathrm{a}$ & $0.68 \mathrm{a}$ & $0.77 \mathrm{a}$ \\
B2 $(600 \mathrm{~kg} / \mathrm{ha})$ & $0.44 \mathrm{a}$ & $0.60 \mathrm{a}$ & $0.71 \mathrm{a}$ & $0.75 \mathrm{a}$ \\
B3 $(700 \mathrm{~kg} / \mathrm{ha})$ & $0.46 \mathrm{a}$ & $0.60 \mathrm{a}$ & $0.72 \mathrm{a}$ & $0.81 \mathrm{a}$ \\
\hline
\end{tabular}

Description: The numbers followed by the same letter in the same row and column are not significantly different from the DMRT test $(\alpha=0.05)$.

At the age of 42 days of observation on the treatment of a spacing of $20 \times 70 \mathrm{~cm}$ there were significant differences, this was estimated at a spacing of $20 \times 70 \mathrm{~cm}$ which was within the boundary which allowed the availability of nutrients, moisture and sunlight to suit the needs of plants for good growth. In accordance with the opinion of Maurya et al. (2013) explained that competition between plants will not occur if population density has not reached the limit where the resources needed by plants 
are limited. At a closer spacing, the competition between plants is higher than the spacing of the plants. This is also supported by the opinion of Harjadi (1993), competition between plants will occur if the needs of plants to grow are limited, the needs of these plants are in the form of water, nutrients, and sunlight.

\section{Long Pods}

Based on the results of analysis of variance (ANOVA) level of $5 \%$ showed that there was no significant interaction between treatment of planting distance $(\mathrm{J})$ and bioslurry dose $(B)$ on pod length of beans in all harvests, but there were significant differences in harvest 1 which can be seen in the table 3 of the following:

Table 3. Pod Length $(\mathrm{cm})$ of Bean on the Effect of Distance $(\mathrm{J})$ and Bioslurry Dosage $(B)$

\begin{tabular}{llll}
\hline & \multicolumn{2}{l}{ Pod Length $(\mathrm{cm})$} \\
Treatment & Harvest 1 & Harvest 2 & Harvest 3 \\
\hline Planting Distance & & & \\
J1 (20x50) & $17.13 \mathrm{~b}$ & $17.64 \mathrm{a}$ & $18.46 \mathrm{a}$ \\
J2 $(20 \times 60)$ & $17.30 \mathrm{~b}$ & $17.99 \mathrm{a}$ & $18.07 \mathrm{a}$ \\
J3 $(20 \times 70)$ & $16.88 \mathrm{a}$ & $17.69 \mathrm{a}$ & $18.38 \mathrm{a}$ \\
Bioslurry dosage & & & \\
B1 (500 kg/ha) & $17.09 \mathrm{a}$ & $17.81 \mathrm{a}$ & $18.20 \mathrm{a}$ \\
B2 (600 kg/ha) & $17.13 \mathrm{a}$ & $17.71 \mathrm{a}$ & $18.37 \mathrm{a}$ \\
B3 (700 kg/ha) & $17.10 \mathrm{a}$ & $17.80 \mathrm{a}$ & $18.35 \mathrm{a}$ \\
\hline
\end{tabular}

Description: The numbers followed by the same letter in the same row and column are not significantly different from the DMRT test $(\alpha=0.05)$.

Isbandi (1983) explained that plant growth begins with the formation of vegetative organs such as roots, stems and leaves that require carbohydrates, starch and protein in the process of growth. These organic compounds are obtained from plants from the results of photosynthesis which are then translocated to all parts of the plant to increase plant growth. In addition to increasing plant growth, optimal photosynthesis processes also affect the generative phase, thereby increasing crop yields. This is supported by Prawita and Condronegoro (1994), that plant 
growth includes the process of division, enlargement, and cell differentiation that occurs in meristem tissue. Cell division that occurs by mitosis in meristem tissue results in the formation of new twigs, branches and shoots. Thus, tenuous spacing can improve photosynthesis and produce high carbohydrates, starches and proteins so as to increase growth and yield on beans.

\section{Number of Pods}

In table 4 it can be seen that there is a real interaction between treatment of spacing $(\mathrm{J})$ and bioslurry dose $(B)$ for the total number of pods of beans.

Table 4. Number of Pods of Bean on the Effect of Distance $(\mathrm{J})$ and Dosage of Bioslurry (B)

\begin{tabular}{ll}
\hline Treatment & Total Number of Pods \\
\hline J1B1 & $50.11 \mathrm{a}$ \\
J1B2 & $48.11 \mathrm{a}$ \\
J1B3 & $53.67 \mathrm{a}$ \\
J2B1 & $51 \quad \mathrm{a}$ \\
J2B2 & $52.11 \mathrm{a}$ \\
J2B3 & $59.33 \mathrm{ab}$ \\
J3B1 & $49.11 \mathrm{a}$ \\
J3B2 & $55.78 \mathrm{a}$ \\
J3B3 & $52.89 \mathrm{a}$ \\
\hline BNJ 0.05 & 8.29
\end{tabular}

Description: The numbers followed by the same letters in the same row and column show no significant difference in the BNJ test $(\alpha=0.05)$.

In the treatment of plant spacing and bioslurry doses which gave the best results, namely the treatment of spacing of $20 \times 60 \mathrm{~cm}$ and bioslurry dose of $700 \mathrm{~kg} \cdot \mathrm{ha}-1$ (J2B3) of 59.33. This is thought to be a tenuous spacing capable of providing an opportunity for plants to absorb nutrients and sunlight to be fulfilled, so that plants are able to minimize competition in the absorption of nutrients and sunlight which can affect plant growth and production. In accordance with the opinion of Munandir (1988), states that the more planted spacing is applied, the more plant populations in broad units can increase competition between plants in absorbing nutrients, water and sunlight. Conversely, if the spacing applied is 
increasingly tenuous, the plant population by unit area is small. So that the competition between plants in absorbing nutrients and small sunlight can maximize photosynthesis to increase plant growth.

\section{E. Pod Weight by Plant}

In table 5 it can be seen that there is a real interaction between the treatment of planting distance $(\mathrm{J})$ and the bioslurry dose $(B)$ on the weight of pods by plant on beans in all crops.

Table 5. Weight of Pods by Plant $(\mathrm{g})$ of Bean on the Effect of Distance $(\mathrm{J})$ and Bioslurry Dosage (B)

\begin{tabular}{lllll}
\hline \multirow{2}{*}{ Treatment } & \multicolumn{4}{l}{ pod weights / plants $(\mathrm{g})$} \\
& Harvest 1 & Harvest 2 & Harvest 3 & Total \\
\hline J1B1 & $81.66 \mathrm{~cd}$ & $89.44 \mathrm{ab}$ & $173.75 \mathrm{~b}$ & $344.86 \mathrm{~b}$ \\
J1B2 & $54.44 \mathrm{a}$ & $65.83 \mathrm{a}$ & $147.92 \mathrm{a}$ & $268.19 \mathrm{a}$ \\
J1B3 & $50.83 \mathrm{a}$ & $60.55 \mathrm{a}$ & $164.45 \mathrm{a}$ & $275.83 \mathrm{a}$ \\
J2B1 & $60.55 \mathrm{a}$ & $78.33 \mathrm{ab}$ & $159.17 \mathrm{a}$ & $298.05 \mathrm{~b}$ \\
J2B2 & $79.44 \mathrm{c}$ & $113.33 \mathrm{~b}$ & $197.5 \mathrm{~b}$ & $390.27 \mathrm{c}$ \\
J2B3 & $78.05 \mathrm{bc}$ & $105.42 \mathrm{~b}$ & $190.83 \mathrm{~b}$ & $374.30 \mathrm{bc}$ \\
J3B1 & $60.27 \mathrm{a}$ & $80.35 \mathrm{a}$ & $112.08 \mathrm{a}$ & $252.70 \mathrm{a}$ \\
J3B2 & $66.66 \mathrm{~b}$ & $80 \mathrm{ab}$ & $190 \mathrm{~b}$ & $336.66 \mathrm{ab}$ \\
J3B3 & $64.72 \mathrm{ab}$ & $89.72 \mathrm{ab}$ & $196.11 \mathrm{~b}$ & $350.55 \mathrm{~b}$ \\
\hline BNJ 0.05 & 14.08 & 29.67 & 49.66 & 68.50 \\
\hline Description: The numbers followed by the same letters in the same row and column
\end{tabular}

Description: The numbers followed by the same letters in the same row and column show no significant difference in the tukey test $(\alpha=0.05)$.

From the results of the $5 \%$ tukey test the highest average on the combination of treatment spacing of $20 \times 60 \mathrm{~cm}$ and bioslurry dose of 600 kg. Ha-1 (J2B2) is equal to $390.27 \mathrm{gr}$ and the lowest treatment combination of planting spacing of $20 \times 70 \mathrm{~cm}$ with a dose of $500 \mathrm{~kg} .-1$ (J3B1) which is equal to $252.70 \mathrm{gr}$. It is assumed that the tight spacing can increase the yield of pod weights by plant due to the narrow spacing having a high plant population. This is in accordance with the opinion of Karmono, et al (1990), that the implementation of a tight spacing has a high number of plant populations by unit area so as to reduce production by individual plant. The decline in production by individual plant can be 
balanced by a large population so that more production by plot will affect the yield of pod weights by plot.

Increasing the weight of pods by plant, besides being influenced by the application of spacing, is also influenced by the role of bioslurry fertilizers which can increase the growth and development of beans. Bioslurry can increase crop production because it contains macro nutrients needed by plants such as phosphorus and potassium which function as raw materials in the process of forming certain proteins and carbohydrates to assist in the assimilation process and accelerate the flowering process, cooking seeds and fruit (Cahyono, 2007 and Barus et al., 2014).

\section{F. Weight of pods by plot}

From the results of the tukey test the level of $5 \%$ showed that there was a real interaction between the treatment of spacing $(J)$ and the dose of bioslurry (B) at all harvests.

Table 6. Weight of Pods by plot (g) Bean on the Effect of Distance (J) and Bioslurry Dosage (B)

\begin{tabular}{lllll}
\hline \multirow{2}{*}{ Treatment } & \multicolumn{3}{l}{ Pod Weight $(\mathrm{g})$} & \\
& Harvest 1 & Harvest 2 & Harvest 3 & Total \\
\hline J1B1 & $941.67 \mathrm{~b}$ & $1353.33 \mathrm{~b}$ & $2562.5 \mathrm{a}$ & $4857.5 \mathrm{a}$ \\
J1B2 & $691.67 \mathrm{a}$ & $875 \mathrm{a}$ & $2662.5 \mathrm{a}$ & $4229.17 \mathrm{a}$ \\
J1B3 & $942.5 \mathrm{~b}$ & $1475 \mathrm{~b}$ & $3573 \mathrm{~b}$ & $5992.5 \mathrm{~b}$ \\
J2B1 & $768.33 \mathrm{a}$ & $1216.25 \mathrm{ab}$ & $2330.33 \mathrm{a}$ & $5429.58 \mathrm{ab}$ \\
J2B2 & $772.5 \mathrm{a}$ & $1273.75 \mathrm{~b}$ & $3558.75 \mathrm{~b}$ & $5605 \mathrm{~b}$ \\
J2B3 & $992.5 \mathrm{~b}$ & $2041.25 \mathrm{c}$ & $2960 \mathrm{a}$ & $5993.75 \mathrm{~b}$ \\
J3B1 & $550 \mathrm{a}$ & $661.67 \mathrm{a}$ & $3556.25 \mathrm{ab}$ & $4767.92 \mathrm{a}$ \\
J3B2 & $772.5 \mathrm{a}$ & $1425 \mathrm{~b}$ & $3648.75 \mathrm{~b}$ & $5846.25 \mathrm{~b}$ \\
J3B3 & $905 \mathrm{ab}$ & $1227.5 \mathrm{~b}$ & $3557.5 \mathrm{~b}$ & $5690 \mathrm{~b}$ \\
\hline BNJ 0.05 & 286.57 & 426.85 & 1111.19 & 709.99 \\
\hline Description: The numbers followed by the same letters in the same row and column show
\end{tabular}

Description: The numbers followed by the same letters in the same row and column show no significant difference in the tukey test $(\alpha=0.05)$.

From the table above, it can be seen that there is an interaction between treatment of spacing $(\mathrm{J})$ and bioslurry dose (B) on pod weights by plot. Where, the combination of treatment of plant spacing and bioslurry 
doses produced the highest total weight of pods at a treatment distance of $20 \times 60 \mathrm{~cm}$ with a bioslurry dose of $700 \mathrm{~kg} \cdot \mathrm{ha}-1$ (J2B3) which was 5993.75 gr. This is thought to be a tenuous spacing which makes it easier for plants to absorb sunlight and provide bioslurry doses that are quite capable of increasing the nutrient content in the soil, so that nutrients for plants are sufficient and can optimize photosynthesis. In addition, the plant population by unit area is also able to increase the weight of pods by plot.

Karmono et al (1990), stated that the plant spacing determines the plant density (plant desinty) of a plant and both are interconnected in determining the high and low production of plants by unit area. Plant products by unit area are equal to production by plant multiplied by plant density, namely the number of plants by unit area or plant population by plot. This is in accordance with the opinion of William and Yoseph (1974) who explained that pod weight by plot was determined by the number of plants by plot and the weight of pods by plant, the number of plant populations by plot determined by spacing. While the weight of pods by plant is determined by the level of competition between plants in absorbing nutrients, sunlight and water.

Besides being influenced by the application of spacing, it is also influenced by the role of bioslurry fertilizers which contain macro and micro elements needed by plants, such as phosphorus. According to Sarief (1989) phosphorus is a part of the cell nucleus that has an important role in the process of cell division and is able to stimulate the growth of roots and young plants that have an effect on increasing nutrient absorption. Increased absorption of nutrients for plants causes photosynthesis to run optimally, so that it can increase the determination of proteins, carbohydrates and starch which will then be translocated to food reserves, namely fruit. The formation of this fruit will affect the weight and size of a larger fruit (Soepardi, 1985).

The statement is in accordance with Hakim (1994) that the increasing absorption of nutrient smoothly will have an effect on the optimal 
photosynthesis process so that the formation of proteins, carbohydrates and starch is not inhibited. The results of the photosynthesis process are translocated to all parts of the plant to stimulate growth and the rest will be translocated to other parts of the plant, namely pods that can affect the weight of the pods formed. This is supported by Harjadi (1993) that increasing vegetative growth will cause the photosynthesis process to run smoothly and photosynthetic results will be used for photosynthetic plants for growth and the rest will be stored as food reserves so that the pods have a higher weight.

\section{CONCLUSION}

There is an interaction between the treatment of spacing with bioslurry doses on variable number of pods, pod weights by plant and pod weights by plot. The best results were achieved at a treatment spacing of $20 \times 60 \mathrm{~cm}$ with a bioslurry dose of $700 \mathrm{~kg}$. Ha-1 (J2B3) for variable pods amounting to 59.33 and pod weights by plant of $390.27 \mathrm{gr}$. While the variable weight of pods by plot obtained the best results of $5993.75 \mathrm{gr}$ on a treatment spacing of $20 \times 60 \mathrm{~cm}$ with a bioslurry dose of $700 \mathrm{~kg}$.ha-1.

\section{REFERENCES}

Agus S. 2013. Management and Use of Biobio-slurry. https: // www. academia.edu/10389621/Pengelola_dan_Pemanfaat_Biobio-slurry. Retrieved 31 December 2015.

Andrianto, and N. Indrianto. 2004. Cultivation and farm analysis. Absolute. Yogyakarta.

Central Bureau of Statistics (BPS). Accessed from https://www.bps.go.id/, accessed on March 1, 2016 at 20:20 WIB.

Barus W.A, H. Khair, M.A. Siregar. 2014. Response to Growth and Production of Green Beans (Phaseolus radiatus L.) Due to Use of Liquid Organic Fertilizers and TSP Fertilizers. Agrium 19 (1): 08521077. 
JOSAR, Vol. 1 No. 2 September, 2018; p-ISSN: 2502-8251; e-ISSN: 2503-1155

Copyrights@ Balitar Islamic University, Blitar-Indonesia https://ejournal.unisbablitar.ac.id/index.php/josar

Cahyono. 2007. Beans, Cultivation Techniques and Farming Analysis.Kanisius Publisher.

Cahyono Bambang, 2003. Bean Beans Cultivation Technique and Farm Business Analysis. Kanisius. Yogyakarta.

Hakim, N. 1994. Basics of Soil Science. University of Lampung. Lampung.

Harjadi, S.S. 1996. Introduction to Agronomy. Gramedia. Jakarta.

Isbandi, D. 1983. Plant Growth and Development. Department.

Maurya, R. P., J. A. Bailey, and J.S.A. Chandler. 2013. Impact of plant spacing and picking intervals on growth, fruit quality and yield of okra (Abelmoschus esculentus (L.) Moench). American Journal of Agriculture and Forestry 1 (4): 48-54.

Prawita, WS. and P. Condronegoro. 1994. Fundamentals of Plant Physiology, IPB Press. Bogor.

Setyanti, Y. H. 2013. Photosynthetic Characteristics and Uptake of Alfalfa Forage Phosphorus (Medicago sativa) at Different Cutting and Fertilizing Nitrogen Height. Animal Agriculture. 2 (1): 86-96

William, C.N. \& K. Joseph. 1974. Climate, soil and crop production in the humid Tropica (Revised Ed). Oxford University Press, Kualalumpur: $177 \mathrm{pp}$.

Yunnan Normal University. 2010. About Bio-Slurry. http: //www.biru. or.id/ index.php / bio-bio-slurry /. Retrieved November 1, 2015. 